\title{
Karl Marx and the IwMA Revisited
}

\author{
Jürgen Herres
}

London, May 1870. In a back room in Holborn a meeting of the General Council of the International Working Men's Association (IWMA) took place under dramatic circumstances. English union leaders and European émigrés were present. A number of "press reporters, greedy for news" were present as well, as Karl Marx reported Friedrich Engels in Manchester, since "rumours had been spread in London" that the members of the General Council were to be arrested in the meeting room. ${ }^{1}$

Just before, leading members of the IWMA, called simply the International, had been arrested in Paris and other French cities. They were accused of plotting a conspiracy against the empire and the assassination of Napoleon III. It was a transparent police manoeuvre. The French Emperor wanted to have his personal sovereignty affirmed in a plebiscite. It became his last big success. The crime of the Paris section of the International merely consisted of appealing to abstention from voting as a demonstration against the Empire and for the social republic. ${ }^{2}$

In London an English newspaper reporter followed the meeting of the General Council of the IWMA. English union leaders and European émigrés excitedly discussed the purpose and content of a public declaration. A while later, more French intellectuals joined, who had been to a revolutionary dinner. The British unionists "always come back to the point that something must be sent to the papers to prove that they do not agree with assassination". The nonEnglish members on the other hand wanted the regime to be condemned. ${ }^{3}$

* Many thanks to Matthias Thompson for translating the text.

1 Marx to Engels, 7 May 1870. (Karl Marx, Frederick Engels. Collected Works (Moscow 1988), vol. 43, p. 504, [hereafter, MECW].)

2 See Marx-Engels-Gesamtausgabe [hereafter, MEGA ${ }^{2}$ ], vol. I/21, p. 231/232, 771/772, 1142 and 1152/3; Julian P.W. Archer, The First International in France, 1864-1871 (Lanham, 1997), pp. 204-206.

3 "A meeting of conspirators" in The Northern Echo (Darlington) No. 165 (13. July 1870), p. 4. - In 1864-65, the General Council comprised thirty to fifty members; in 1866-71, twenty-five to thirty; and in $1871^{-72}$, forty to fifty. For the entire period, $1864-72$, the total came to approximately 200 persons. This council consisted equally of British union members, London radicals, and émigrés living in London. Among the British members were George Odger, George

(C) JÜRGEN HERRES, 2018 | DOI 10.1163/9789004335462_020 
After some three hours of rambling discussion a sort of compromise was reached. "The part speaking against assassination is made clearer and stronger", the reporter told. "At the request of the British, some beautiful passages about the sun conspiring against darkness are allowed to stand to please the foreigners." In the declaration of the General Council the tasks of the International are emphasized: "The special mission of all our branches [is] to act ... as centres for the organisation of the working class". And is "also to aid ... all political movements tending to the accomplishment of our ultimate end, the economical emancipation of the working class". All of this happened "in open daylight". "Every form of secret society" was rejected. The workers would "conspire publicly", "as the sun conspires against darkness". The declaration concludes with: "The noisy and violent measures against our French sections are exclusively intending ... the manipulation of the plebiscite." ${ }^{5}$

The declaration was written by Marx. His handwritten text was glued into the minute book. ${ }^{6}$ Almost every meeting of the General Council was recorded in such a minute. Four manuscript minute books have survived. The British reporter described how at the beginning of the meeting the secretary deposited a heavy minute-book upon the table. The secretary, a German tailor and refugee, seemed to have carried that great tome all the way from the other end of London.

The journalist also left us with a remarkable description of Marx: "The most noticeable man in the company is a German professor; he is of middle-age, and has a handsome leonine face; and is evidently what an American would call the 'boss' of the meeting."

Marx was not a founding initiator. But he was present at the creation of the International. He authored its programmatic documents and drafted most of its statements, appeals, and reports. During eight years, from 1864 to 1872 , Marx participated almost every Tuesday evening in the consultations of the General Council, which coordinated the international network of workers from

Howell, Edwin Coulson, William Randal Cremer, and William Allan, who presided over some of the largest British unions and who had created the London Trades Council in 1860. Wolfgang Schieder, Karl Marx als Politiker (München, 1991), pp. 125/126; $\mathrm{MEGA}^{2}$, vol. I/21, pp. 17931802 and 1986-1991; Keith Robinson, Karl Marx, the International Working Men's Association, and London Radicalism, 1864-1972 (PhD, University of Manchester, 1976), pp. 74-98, 181-287, (Appendix I and IV).

4 "A meeting of conspirators" in The Northern Echo (Darlington), No. 165 (13. July 1870), p. 4.

5 MEGA', vol. I/21, p. 771/772.

6 MEGA 2 , vol. I/21, p. 2074.

7 "A meeting of conspirators" in The Northern Echo (Darlington), No. 165 (13. July 1870), p. 4. - See MEGA', vol. I/21, p. 2073. 
London. ${ }^{8}$ Was Marx really to be seen as the "boss" of the International? And if so, then in which way?

To answer these questions, I will first plead for a re-definition. We should view the International Workingmen's Association as a network of different European groups of workers and reformers, whose annual meetings in Switzerland and Belgium should be regarded as the birthplace of European socialism. ${ }^{9}$

Next I will explore Marx' role. I will especially emphasize the middle phase of the history of the International, the years from 1866 to 1871, from the first European workers' congress in Geneva to the Franco-Prussian War. ${ }^{10}$

\section{First Modern Globalisation and the International}

Our view on the nineteenth century has changed, through European integration, but especially through globalisation. While historians such as E.J. Hobsbawm and H.-U. Wehler have presented the nineteenth century as an era of a double revolution in politics and economy, we now also recognise the parallel emergence of a first modern wave of globalisation, which lasted until the beginning of the first world war in $1914 \cdot{ }^{11}$ It was an epoch of big changes and

Schieder, Karl Marx als Politiker, pp. 74-117.

9 See Julius Braunthal, Geschichte der Internationale, 2. ed. (Berlin [etc.], 1978), vol. 1; Henryk Katz, The Emancipation of labor. A history of the First International (New York [etc.], 1992); Marcel van der Linden, "The rise and fall of the First International. An Interpretation" in Frits van Holthoon and Marcel van der Linden (eds.), Internationalism in the labour movement 1830-1930 (Leiden, 1988), vol. 1, pp. 323-335; I.A. Bach, L.I. Golman und W.E. Kunina (eds.) Die Erste Internationale, vol. 1-2 (Moskau 1981); James Guillaume L'Internationale. Documents et Souvenirs (1864-1872), vol. 1-4. (Paris 1905, 1907, 1909 and 1910, new ed. Paris 1985); Henry Collins and Chimen Abramsky, Karl Marx and the British labour movement. Years of the First International (London [etc.], 1965), pp. 59 ff.; Timothy Messer-Kruse, The Yankee International. Marxism and the American reform tradition, 1848-1876 (Chapel Hill [etc.], 1998); Miklés Molnár, Le déclin de la Première Internationale (Genève, 1963); Ludolf Herbst, Die erste Internationale als Problem der deutschen Politik in der Reichsgründungszeit (Göttingen, 1975); Geoff Eley, Forging democracy. The history of the Left in Europe, 1850-200o (Oxford, 2002), pp. 33-63; F[rancis] S.L. Lyons, Internationalism in Europe, 1815-1914 (Leyden, 1963), pp. 164-179; La Première Internationale. Linstitution L'implantation - Le rayonnement, Paris 16-18 novembre 1964 (Paris, 1968).

10 See Jürgen Herres, "Einführung", in MEGA² vol. I/21, pp. 1125-1228. Online: urn:nbn:de: kobv:b4-opus-10883.

11 See Richard E. Baldwin and Philippe Martin, "Two Waves of Globalization. Superficial Similarities, Fundamental Differences", in Horst Siebert (ed), Globalization and Labor (Tübingen, 1999), pp. 5-9 and 11-14; Kevin H. O'Rourke and Jeffrey G. Williamson, 
inconsistencies, which in some respect feels closer to our current experiences than much of the twentieth century.

In view of this, the history of the International deserves to be reconsidered without any ideological distortions. Notably, the International is hardly accorded a footnote in the current interpretations of world and global history - although it was the International which conceptualized certain terms still important for present debates. Due to the IWMA, the term "international" entered the lexicons and encyclopaedias of the late nineteenth century. ${ }^{12}$ Without doubt, the "classical" history of the worker's movement with its all too narrow definition of the term "worker" and through its party- and national historical orientation which has never been sufficiently overcome significantly paved the way for this marginalization of the International in broader global historiographical contexts.

In the last fifty years a large number of important source books and analyses about the history of the International have been published. I am referring to the minutes of the London General Council published in Moscow and the minutes of the congresses of the International edited in Geneva. ${ }^{13}$ These achievements in research and editing have been recently significantly complemented by the Marx-Engels-Gesamtausgabe (MEGA ${ }^{2}$ ). I myself have edited documents from 1867 to 1871 in the MEGA - that is the publication of the complete writings of Marx and Engels - and re-deciphered the minutes of the General Council for that purpose. ${ }^{14}$ Today all archives are open to the public, including the ones in Moscow.

The resolutions and proclamations of the International, the minutes and speeches, but also the copious correspondence should be re-examined. For far too long these texts were mainly seen as expressions of party political and ideological infighting. They were actually controversial debates about

Globalization and History. The Evolution of a Nineteenth-century Atlantic Economy, 3. ed. (Cambridge, 1999), pp. 11-14, 33-41 and 208-223; Knut Borchardt, Globalisierung in historischer Perspektive (München, 2001), pp. 8-15.

12 For the first time in 1873, Larousse's Grand Dictionnaire regarded the term "International" as a noun. See Peter Friedemann, Lucian Hölscher, "Internationale, International, Internationalismus", in Otto Brunner et al. (eds), Geschichtliche Grundbegriffe, vol. 3 (Stuttgart, 1982), p. 368, 371 and 380-387; Jean Dubois, Le vocabulaire politique et social en France de 1869 à 1872 (Paris, 1964), p. 134.

13 The General Council of the First International. Minutes, 5 vol. (Moscow, 1964-1968); Jacques Freymond (ed.), La Première Internationale. Recueil de documents, vol. 1-2 (Genève 1962); vol. 3-4 (Genève 1971).

14 MEGA $^{2}$ vol. I/21, pp. 511-696 and 707-905. - See MEGA ${ }^{2}$ vol. I/20, pp. 265-450 and 477-591; vol. I/22, pp. 519-640. 
important social, economic and political questions and problems. In these debates we can see, how in the historical context of the industrial revolution and the first modern wave of globalisation a transnational European exchange of ideas and practices occurred.

The IWMA is to be seen as an attempt, to develop ideas, concepts and techniques transnationally. That way it partly succeeded in making the globality of the interests of the workers beyond national borders and their union reality. Until then this globalization had only been imagined.

The International caused an exchange of information about political and social questions and forms of organization. However, it especially acted as a mediator and translator of ideas. It advanced the process of understanding the importance of workers' interest. This was a conflictual process that nevertheless served to integrate different actors and groups all over Europe. In connection with an eventually unsuccessful strike in Basel, a member of the General Council confidently claimed in the London Times that: "Trade unionism will soon be co-existing with civilization. By the agency of the IWMA the movement has spread quicker than it otherwise would have done". ${ }^{15}$ In the year 1869 Marx was convinced: "The community of action the IWMA is calling into being, the exchange of ideas ... and ... the direct discussions at the general congresses would ... gradually create a common theoretical program for the general workers' movement."16

From the beginning the International was a movement transcending social questions and interests. In 1863 the British and French workers put pressure on their governments to support the Polish uprising. In conferences of solidarity for the uprising Poles in April and July 1863 in London, the history of the International began. ${ }^{17}$ The British workers' leaders were against a purely economic alignment of the unions. Trade unions must act politically as well as industrially to secure for workers their equality and rights.

The International Workingmen's Association created a communication network of European workers and established itself as their voice in the European public. The congresses of the International in Geneva in 1866, in Lausanne in 1867, in Brussels in 1868, in Basel 1869 and in The Hague in 1872 were noticed

\footnotetext{
15 "Trade disputes on the Continent" (by a Unionist), in The Times (London), No 26354, 6. February 1869, p. 4. - See MEGA2 , vol. I/21, pp. 1147/8.

16 Marx to Engels, 5 March 1869. (MECW, vol. 46, p. 235/6.) - See MEGA2, vol. I/21, pp. 116 and 118.

17 See D. Rjasanov, "Zur Geschichte der ersten Internationale. I. Die Entstehung der Internationalen Arbeiterassoziation", in Marx-Engels-Archiv (Frankfurt am Main), vol. 1, 1926, pp. 119-202; Archer, The First International in France, 1864-1871, pp. 1-19 and 33-35.
} 
throughout Europe. The London Times published detailed correspondence reports, which were reprinted and commented on by many European newspapers. In 1867 the Times wrote in an editorial about the Lausanne Congress: "It will be nothing less than a new world, we really believe, when Englishmen and foreigners find themselves able to work together". ${ }^{18}$ In 1870 the congress planned in Paris did not take place because of the Franco-Prussian War. In Paris, the black priest Sella Martin (1832-1876) had been supposed to represent black US-American workers for the first time. Martin had grown up as a slave and fled to Canada. ${ }^{19}$

The International was a very fragile construct. As a network it was organizationally vulnerable, without any financial resources and the association was hampered by severe political and ideological infighting. It constantly faced all kinds of crises that can be imagined. From the beginning there was a wide gap between aspiration and reality. This was also reflected in the aspirations and actions of the most prominent member of the association - Karl Marx.

\section{“... what an American would call the 'boss"}

Until twenty years ago there was a heated debate about Marx's influence on the IWMA. While some declared Marx the actual leader of the International, who was mainly concerned with enforcing Marxism, others told the history of the International basically without Marx. Marxist-Leninist research claimed a unique share of Marx and his theories in the creation and policies of the International. To them, the International was a step in the necessary and historically unavoidable victory of Marxism over the different forms of petty bourgeois socialism. These ideologies and instrumentalisations continue to have an effect until today, whether we are aware of it or not.

I am giving prominence to the historic Marx, not the state ideologist of the twentieth century or the visionary of anti-colonial liberation movements and anti-authoritarian student movements. The interesting story in our context deals with the social philosopher, social critic and revolutionary of the nineteenth century, with all inconsistencies and ambivalence that were a part of him and his times.

Marx was neither one of the activist professional revolutionaries, spawned only by the twentieth century, nor did he, as a scientist and analyst of capitalism,

18 "During the last few days we have reported ...", in The Times (London), No. 25914 (12 September 1867), p. 6.

19 See MEGA ${ }^{2}$ vol. I/21, p. 233, 780-782, 786, 1158 and 2083. 
leave a finalized or at least cohesive work behind. Instead his work remained a fragment in central parts. And its political and scientific development was anything but a straightforward. He discussed many political questions only in the form of newspaper articles.

When the International was founded in 1864, Marx was working on the third overall design of his "Critique of Capitalist Economy", which like the previous two drafts remained incomplete. ${ }^{20}$ In 1867 the first volume of his Kapital was published; the only one to be published in his lifetime. The books nowadays known as volumes two and three were published after Marx' death from his estate. When the International was laid to rest at the Hague Congress, only the first edition of the Kapital which was about 1,00o copies, had been sold. ${ }^{21}$ For comparison: In 1859 the first edition of Darwin's book On the Origin of Species, 1000 copies as well, had already been sold out on the first day.

The different Marxisms successfully separated Marx from his intellectual and communicative environment. He found himself be stylized to be the founder of a scientific ideology, a kind of a political religion, and the leader of the German and international workers, who allegedly sang praises of a communist cadre party. Against this distorting traditions, it is of indispensable importance to put Marx back into his historical contexts. It may sound paradoxical, but only this "Historisierung" (historisation) allows a discussion about potentials, which may make him and his times more "modern" and accessible for us today.

Marx never held a prominent official position within the International. In 1866 he declined the offer to become president. ${ }^{22}$ But he significantly contributed to the International not just remaining an inspiring idea - like many previous initiatives, but becoming political reality and becoming politically active for almost a decade.

Marx' position was first and foremost an intellectually dominant one. He played a critical role in moulding the identity of the International. He played an important role in conceptualizing workers emancipation as a global project and articulating a transnational community of workers' interests. We have to read his writings and speeches as critical responses to European discussions.

His texts attracted interest, generalized and offered interpretations. They presented arguments, but they also were emotionally startling and suggestive.

20 Today it is possible to read all these drafts in the MEGA. See MEGA ${ }^{2}$ vol. II/1-15. - Gerald Hubmann, Regina Roth, "Die 'Kapital'-Abteilung der MEGA. Einleitung und Überblick”, in Marx-Engels Jahrbuch 2012/13 (Berlin, 2013), pp. 60-69.

21 MEGA ${ }^{2}$ vol. I/21, pp. 1200-1218.

$22 \quad \mathrm{MEGA}^{2}$ vol. I/20, p. 485. 
Through their eloquence and analytical strength his texts were able to fill the communicative space opened by the International. On the one hand we can hear the echo of contemporary discourse and debates in Marx' texts and speeches. On the other hand he creatively and inspirationally influenced these debates.

Looking at the minutes of the General Council, we get to know a Marx who was committed to dealing with European social, economic and workers' questions week after week. A Marx, who determined the main topics, recited analyses and could give meaning to events. But also a Marx who was involved in the political networks of relationships and communication.

The appeals and declarations written by Marx were proof and products of exchange, not party statements he could autocratically proclaim. They are like the public declaration of May 1870 - to be seen in the context of the discussions of the General Council and in the European trade unions and workers' movements. Famous appeals, even if they were controversially debated in the General Council, originated against this background. He also very consciously considered the sensitivities of the British public. In September 1870 he reminded Engels "that the General Council has to deal with susceptibilities in all directions", and thus he could not write in a way he would have done in his familiar cooperation with Engels. ${ }^{23}$

On July 19th 1870 , four days after the Franco-Prussian war broke out, in a meeting of the General Council Marx was assigned the task to draft a manifesto against the war. Marx asked the other members of the General Council, to express their opinions. The chairman of the meeting suggested that all members should explain their opinions, which were to serve as a guideline for Marx. ${ }^{24}$ In the manifesto Napoleon III is blamed for the outbreak of the war and the end of his reign was foreseen. Although Prussia is declared complicit in the unfolding events, Marx assumed a "defensive character of the war on the German side". ${ }^{25}$ After Napoleon had been overthrown the General Council advocated immediate peace without any cession of territory, in a second address which was also written by Marx. ${ }^{26}$

I would like to look at two topics in more detail: firstly Marx' plea for a transnational solidarity of workers, and secondly his plea for a European perspective.

In 1864 Marx wrote the founding program of the International, the Inaugural address. It is a document comparable to the Communist Manifesto. In it

\footnotetext{
23 Marx to Engels, 14 September 1870. (MECW, vol. 44, pp. 76/7.)

$24 \mathrm{MEGA}^{2}$ vol. I/21, pp. 807/8.

25 MEGA ${ }^{2}$ vol. I/21, pp. 245-250, 478-484, 1594-1612 and 1744-1750.

$26 \quad$ MEGA $^{2}$ vol. I/21, pp. 485-499 and 1751-1776.
} 
he explains the necessity of a transnational solidarity of workers. It states: "It is a great fact that the misery of the working masses has not diminished from 1848 to 1864 , and yet this period is unrivalled for the development of its industry and the growth of its commerce."27

With this Marx put the basic conviction of these worker activists into words. This can be seen in interviews that leading British members of the International gave the New York newspaper The World in May 1870. "The World" later became famous for Joseph Pulitzer. Robert Applegarth was a member of the General Council of the International and general secretary of one of the most influential British unions of his time - the carpenters and joiners. He told The World: "Those of us who had studied the situation had become convinced that no improvement of machinery, no application, no new colonies, no emigration, no opening of markets, no free trade, not even all these things put together, excellent as they are would do away with the misery of the operative classes....Our claim ... to participate in the fruits of our own labour can only be enforced and realized by the union of all of us."28

For Marx, unions were the ideal class organizations of the workers, politicized unions, who fought social battles with political intentions. This concept was behind the "provisional Rules" which were also written by Marx and were accepted by the first European workers' congress in Geneva in 1866 . They state that the economic emancipation of the working classes was the big goal, which every political movement ought to be subordinate to as a means. ${ }^{29}$ For Marx, parties were midwives for unions at best. That is why in 1869 in Hanover Marx told the German metal unionists who were followers of Ferdinand Lasalle: "All political parties, whatever they may be, without exception, inspire the masses of the workers only temporarily; however the unions mesmerise the masses of the workers for good, only they are capable of truly representing a workers' party and being a bastion against the power of the capital." Marx thought of political workers' parties as some kind of fad. The text of this talk has never been printed in a Marx-Engels-edition. It has only now been documented in the MEGA. ${ }^{30}$

In 1866 Marx wrote a reserved catalogue of tasks of the International for the Geneva Congress in the Instructions for the Delegates of the Provisional General

\footnotetext{
$27 \quad$ MEGA $^{2}$ vol. I/20, p. 3 .

28 "Labor and Capital", in Woodhull \& Claflin's Weekly (New York) No. 3 (28. Mai 1870), pp. $3 / 4$. (Reprint from The World, New York.) - See MEGA2, vol. I/21, p. 1147.

29 MEGA ${ }^{2}$, vol. I/20, p. 658/9 and 688-700; vol. I/21, p. 1141.

$30 \quad \mathrm{MEGA}^{2}$, vol. I/21, p. 906/7 and 2141-2144.
} 
Council. ${ }^{31}$ Later he characterized these Instructions as "part of the platform of principles of the International". ${ }^{2}$ Marx emphasized the importance of limiting the working day to eight hours, of the question of children's and women's labour, of strengthening producers' cooperatives and trade unions, and of an international inquiry into workplace conditions. He explained that he "intentionally restricted himself to such points that would allow direct understanding and cooperation of workers". ${ }^{33}$ Marx always emphasized that the General Council was "not responsible" for the decision of the Brussels Congress to demand nationalization of the mines, trains and forests. This decision can rather be traced back to the initiative of the Brussels members of the International. ${ }^{34}$

For Marx Europe was an area of reference as well as an area of action, but also an area of the future. His horizon transcended national and ethnic boundaries. But throughout his life the nation state remained the central principle of order for him. The Communist Manifesto may state that: "The workers have no fatherland." ${ }^{35}$ But Marx made it clear that politically the revolutionary "proletariat" had to act on a national level. He expected that the solidarity of the proletariat fighting for equal interests and rights would lead to overcoming nations. He considered national statehood and international solidarity of classes to be compatible. He underestimated the explosive force of nationalism, he may have even consciously ignored it. Already in the revolution of 1848 , national rivalries had increased and led to bloody national confrontations.

Marx fought for a Europe of medium-sized states, with power bases and interests restricted to Europe. Marx and Engels saw in the "alliance of the three big western nations" - France, Britain and Germany - the most important "international condition for the political and social liberation for all of Europe". The cooperation of these three nations - Engels wrote 1890 - was to be the "core of the European association", that would "permanently put an end to cabinet- and race wars". ${ }^{36}$

While Marx was writing the Communist Manifesto in 1847, together with other European intellectuals, he founded the Association Démocratique in

\footnotetext{
$31 \quad$ MEGA 2 , vol. I/20, pp. 225-235.

32 MEGA 2 , vol. I/21, p. 104 and 1155/6.

33 Marx to Louis Kugelmann, 9 October 1866. (MECW vol. 42, p. 326.)

34 MEGA ${ }^{2}$ vol. I/21, pp. 670-672, 1157, 1794, 1952-1955.

35 Karl Marx, Friedrich Engels, "Manifest der Kommunistischen Partei", in Karl Marx, Friedrich Engels Werke (Berlin, 1964), vol. 4, p. 479. - See Karl Marx and Friedrich Engels, The Communist Manifesto, ed. by Gareth Stedman Jones (London, 2002); Jürgen Herres, "Rhineland Radicals and the "48ers" in Terrell Carver, James Farr (eds.), The Cambridge Companion to the Communist Manifesto, (Cambridge 2015), pp. 15-31.

36 Engels, "Au Conseil National du Parti Ouvrier Français" (189o), in $\mathrm{MEGA}^{2}$ vol. I/31, p. 287.
} 
Brussels, which planned a big "congress of democrats of all European nations" in 1848. The Brussels Association Démocratique may have been the first organisation that explicitly promoted the "United States of Europe". When the Brussels society discussed the unification of Europe (une Fédération de l'Europe) as a union of democratic republics on 26 December 1847, both Marx and Michael Bakunin were present. ${ }^{37}$

For smaller nations, Marx and Engels accepted only a cultural right to selfdetermination with the exception of the two Catholic victim nations of the nineteenth century. Throughout his life, Marx fought for Poland and Ireland, out of conviction, but especially for political reasons. His strategic conception was the repression and containment of the interests of great powers, especially Russia. From Marx' point of view "the restoration of Poland" was "the annihilation of Russia, the removal of Russia's candidacy for world domination." 38 Thus he declared the "motto of the International Workingmen's association" to be: "A free Europe, based on a free and independent Poland." ${ }^{39}$ He expected the independence of Ireland to cause a revolution in Great Britain..$^{40}$

The sympathy of the International for colonized peoples however, was restricted to denouncing colonial "excesses" and did not question the colonial system as such. Although Marx repeatedly emphasized the Janus-faced character of progress, he considered only "European civilization" capable of development and progress. He considered some European and especially extra-European societies to be cultures of stagnation and regression, which could only move forward if they followed in Europe's footsteps. In the last decade of his life Marx concerned himself more extensively with extra-European societies and tried to expand his analysis, which had so far focused on Western Europe, to a global perspective. ${ }^{41}$

In 1870 Marx temporarily thought that the power political map of Europe might significantly change. Due to the military success of Prussia against France, in his perspective Germany became independent of Russia. And it

37 See Association Démocratique, ayant pour but l'union et la fraternité de tous les peuples. Eine frühe internationale demokratische Vereinigung in Brüssel 1847-1848, ed. by Bert Andréas, Jacques Grandjonc and Hans Pelger (Trier, 2004), p. 359 and 460-462.

38 Karl Marx, Manuskripte über die polnische Frage (1863-1864), ed. by Werner Conze and Dieter Hertz-Eichenrode ('S-Gravenhage 1961), p. 93; Karol Marx, Przyczynki do historii kwestii polskiej (Warzawa 1971), p. 4.

39 MEGA ${ }^{2}$ vol. I/20, p. 132 and 243-247, 286, 290 and 343.

40 Jürgen Herres, "Marx und Engels über Irland. Ein Überblick. Artikel, Briefe, Manuskripte und Schriften" in Marx-Engels Jahrbuch 2011 (Berlin, 2012), pp. 12-27.

41 Kevin B. Anderson, Marx at the Margins. On Nationalism, Ethnicity, and Non-Western Societies (Chicago [etc.], 2010). 
appeared to him that the collapse of the second empire would enable the cooperation of France and Germany to establish republics and social revolution. Therefore he and Engels vehemently opposed the annexation of Alsace and Lorraine. They called the annexation "the biggest misfortune", as it made a great European war "unavoidable" in the future. ${ }^{42}$

Marx's opposition to the annexation of Alsace and Lorraine in the FrancoPrussian war in 1870-1, as well as his advocacy for Poland and Ireland had a remarkably European dimension. His political concept aimed for a Europe of democratised nation states. All chauvinism was alien to him.

\section{Conclusion}

In 1847-8 in the Communist Manifesto and in 1864 in the inaugural address of the IWMA, Marx called upon the workers of the world to unite. The transnational solidarity of workers demanded by Marx had nothing in common with the proletarian internationalism of the twentieth century. That is why I have generally used the adjective transnational instead of international. And that is why I have emphasized the middle phase of the history of the IWMA.

All too often this history of the International has been told from its - admittedly - dramatic end. But that is a distorted perspective. In 1871, after the suppression of the Paris commune in the French capital which was besieged by German troops, the French workers' movement remained inactive for many years; with it the French-British cooperation, on which the International had fundamentally rested, ended as well. The international network was not up to the police persecution of the continental European governments. Furthermore there were structural changes. Globalization which rapidly accelerated after 1870 provoked strong national defensive reactions, protectionism and a radicalisation of nationalism.

Nevertheless the question remains: why did the International proved incapable of adapting to this changed political and overall world economic situation? Did the internationalism of the IWMA in some way really have to give way to national workers' movements?

I highlighted Marx first and foremost as an intellectual mediator, translator, analyst and provider of ideas of the International. In 1871-2 the ambivalence of his political effectiveness, but also the limits of his concepts of workers and revolution became apparent. In 1871 Marx became world-famous as one of the most controversial political radicals through his empathic defence of the Paris 
Commune in the General Council address The Civil War in France.$^{43}$ From the perspective of the European governments he had instigated the uprising of the Paris Commune.

In 1871 Marx urged a greater leading role of the General Council and a stronger politicization of the International: "In presence of an unbridled reaction which violently crushes every effort at emancipation on the part of the working men ... the working class cannot act, as a class, except by constituting itself into a political party". And he "recalls to the members ... that in the militant state of the working class, its economical movement and its political action are indissoluble united". ${ }^{44}$ But this "political party" did not mean the communist cadre party of the twentieth century, but a conscious politicization of the European workers' movements.

Marx failed to move the British labour leaders to political uprising. They rather saw their social achievements jeopardized and gradually withdrew from the International. Marx did not wage the alleged power struggle against Michael Bakunin in 1872 politically or ideologically, but like a state prosecutor, who does not leave out any points that can lead to the conviction of the accused. 45

Without overvaluing the observation of the British journalist mentioned at the beginning, Marx was not the boss of the International. At no point has the General Council been a central committee of underlings.

The impact of the International had less to do with absolute numbers than with its symbolic power. It became the symbol of transnational power of workers even though the membership figures were exaggerated and the allegedly filled cash boxes existed only in the imagination of the police. Marx considerably contributed to this as long as he exercised restraint in his role as a mediator. He failed when he gave up his mediating role. The International opens our view to the debates of the European workers' and opposition movements about important questions of foreign, constitutional, union and social policy in the age of the first modern wave of globalization.

\footnotetext{
43 MEGA ${ }^{2}$ vol. I/22, pp. 13-162 and 179-226. See Figure 19.1.

44 MEGA $^{2}$ vol. I/22, pp. 343/4. - See Molnár, Le déclin de la Première Internationale, pp. 83 and $95 \mathrm{ff}$.

45 See Michael Bakunin, Konflikt mit Marx, ed. by Wolfgang Eckhardt (Berlin, 2011), vol. 2, pp. 68iff.
} 
THE

\title{
CIVIL WAR IN FRANCE.
}

\author{
ADDRESS
}

of

\author{
THE GENERAL COUNCIL
}

OF THE

\section{INTERNATIONAL WORKING-MEN'S}

\section{ASSOCIATION.}

THIRD EDITION, REVISED.

\author{
$\overline{\overline{ }}$ \\ Printed and Published for the Council by \\ EDWARD TRUELOVE, 256, HIGH HOLBORN. \\ 1871.
}

Price Twopence.

FIGURE 19.1 The Civil War in France. Address of the General Council of the IWMA, 1871 . Title page.

PRIVATE COLLECTION. 